\title{
PERFORMANCES COMPARISON BETWEEN URBAN AND RURAL PIG FARMING SYSTEMS IN MANOKWARI, WEST PAPUA PROVINCE INDONESIA
}

\author{
PERBANDINGAN KINERJA ANTARA PETERNAKAN BABI YANG DIPELIHARA \\ DI PERKOTAAN DAN PEDESAAN MANOKWARI, PROVINSI PAPUA BARAT, INDONESIA
}

\author{
Desni Triana Ruli Saragih and Deny Anjelus lyai* \\ Animal Production Department, Faculty of Animal Science, Papua University, Manokwari, 98314
}

Submitted: 26 May 2015, Accepted: 9 September 2015

\begin{abstract}
Pigs are kept both in urban and rural areas. This research identified the performance differences between urban and rural farming systems. The study was conducted in Manokwari regency and involved six districts, i.e. Nothern Manokwari district, Eastern Manokari District, Western Manokwari district, Warmare district, Prafi district and Masni district. Data were analyzed using SPSS version 18.0, an independent-samples $T$ test was run to compare urban and rural pig farming systems. The research found that there were differences of ages and feeding hours $(\mathrm{P}<0.05)$ between those two farming systems. There were no differences in household members, experience, average pig owned, working hours, selling period, litter size and number of farrowing. There are nine point of pig farming improvement that should be done to sustain pig farming systems in Manokwari Papua. Education may be improved by provide informal and skillful education. Pig ownership should be increased. Working hours must be increased. Pig keeping in the pens should be done by farmers. Managing pigs with additional time is important so that pigs will be maintained well. Litter sizes both in urban and rural are low, therefore further improvements are needed. Recording pig productivities must be done by every farmer.
\end{abstract}

(Key words: Arfak pig farmers, Pig performance, Rural pig farming, Urban pig farming)

\section{INTISARI}

Ternak babi dipelihara pada daerah perkotaan dan pedesaan. Tujuan penelitian ini untuk mengetahui perbedaan di antara kedua lokasi. Studi lapangan dilakukan di Manokwari meliputi enam distrik, yaitu Manokwari utara, Manokwari Timur, Manokwari Barat, Warmare, Pradi dan Masni. Data diolah dengan menggunakan SPSS versi 18.0, uji-T dipakai untuk membandingkan peternakan babi perkotaan dan pedesaan. Hasil penelitian menunjukkan bahwa terdapat perbedaan rerata umur dan jumlah waktu pemberian pakan $(P<0.05)$. Karakteristik yang relatif sama yaitu jumlah jiwa/keluarga, pengalaman, jumlah ternak, jumlah jam kerja, periode penjualan, jumlah anak babi, dan jumlah beranak/tahun. Terdapat sembilan faktor yang harus ditingkatkan untuk keberlanjutan sistem peternakan babi di Manokwari, Papua. Aspek pendidikan harus ditingkatkan dengan menyediakan pendidikan informal dan pendidikan keterampilan. Jumlah kepemilikan ternak dan waktu kerja harus ditingkatkan. Membiasakan ternak dipelihara dalam kandang harus dilakukan oleh peternak. Waktu kerja luang untuk ternak harus disediakan sehingga dipelihara dengan baik. Litter size rendah sehingga diperlukan perbaikan lebih lanjut. Oleh karena itu recording produktifitas ternak harus dilakukan setiap peternak.

(Kata kunci: Performan peternakan, Peternak Arfak, Peternakan babi pedesaan, Peternakan babi perkotaan)

\footnotetext{
${ }^{*}$ Korespondensi (corresponding author):

Telp. +62 82399115786

E-mail: da.iyai@yahoo.com
} 


\section{Introduction}

Understanding the differences between urban and rural farming systems is important. It means that urban and rural circumstance has specific characteristic of farming systems. Urban farming systems are usually done with less even no land (landless). This is in contrary with rural farming systems. Urban farming system is done with conventional and waste products. While rural farming systems, pig productions are run with crops and in few parts deal with household wastes.

Papua also has unique characteristics of pig farming systems, e.g. sweet potatobased farming systems (Peters, 2001; Berkmann, 2006) and palm-pig production system (Basna, 2011). The Papuans, both in lowland and upland areas, use local resources and traditional knowledge in their ways of farming pigs. Local breeds, feeds, and housing materials sustain traditional pig farming. However, pork production in central production of livestock in Manokwari is still lagging behind the demands. In Manokwari, pig farming systems are classified into four systems (Iyai, 2008). In general Muys and Westenbrink (1998) classified pig keeping systems into three systems, i.e. free-range "scavenging" pig keeping, semi-intensive and intensive pig keeping. In developed countries, pig production systems are mainly based on commercial-intensive pig keeping systems. In developing countries, such as in Papua New Guinea (Berkmann, 2006), Vietnam (Lemke et al., 2006), India (Deka et al., 2007) and Africa (Lekule and Kyvsgaard, 2003), different production systems co-exist due to different resource availabilities, values and functions, knowledge and traditions.

Although pigs are highly valued, this is not shown in the ways pigs are kept. In Manokwari region, both in rural and urban areas, pigs are raised in free-range, semipenned and penned systems (lyai, 2008). Pens are made from wood and bamboo and roofs are made from aluminium sheets and leaves. In urban areas, numbers of housed pigs are increasing driven by wishes for earning cash, increasing local and regional demands of pork, breeds used, higher labour costs, availability kitchen and restaurant refuses and availability of bank loans and extensionists' services. In urban areas, pig farmers belong to many different ethnic groups. In rural areas, free-range system is commonly practiced due to its low labour cost, available crop residues, available cultural markets, limited access of commercial market and limited wastes of outlets. Although pigs are housed, more pigs still roam around in both urban and rural areas. Most rural pig farmers that have adopted pens still let their pigs scavenge freely. Therefore, it was interested to compare the performances between urban and rural pig farming systems in Manokwari.

\section{Materials and Methods}

The field study was done in Manokwari regency and involved six districts, i.e. Nothern Manokwari district, Eastern Manokwari District, Western Manokwari district, Warmare district, Prafi district and Masni district. Manokwari regency, which has a total area of $14,445 \mathrm{~km}^{2}$, possesses a population of around 161,000 inhabitants with a density of 11,51 heads $\mathrm{km}^{-1}$, and is located at $132^{\circ} 30^{\prime}-134^{\circ} 45^{\prime}$ East Meridian and $0^{\circ} 20^{\prime}-2^{\circ} 25^{\prime}$ South latitude. Manokwari has relatively dense population of around 228 heads per $\mathrm{km}^{2}$. The population in Manokwari is growing in both urban and rural areas, especially in transmigration areas, such as Prafi and Masni districts. Respondents chosen were guided by local extensionists, originated from 15 villages. In urban areas selected farmers originated from Anggrem, Borobudur, Fanindi, Wosi, Amban and Susweni villages, while in rural areas selected farmers originated at Tanah Merah, Nimbai, Waseki, Aimasi, Mokwan, Mimbowi, SP-8 Masni, Bremi and Warbefor villages. Three urban villages, Anggrem, Fanindi and Wosi, are situated on coastal areas of Manokwari as well as the two rural villages, i.e. Bremi and Warbefor, which are located in the Northern coastal line of Manokwari. Anggrem, Fanindi and Wosi are located at less than $5 \mathrm{~m}$ above sea level. Amban and Susweni are located at $110 \mathrm{~m}$ above sea level. The rural villages Bremi and Warbefor, are located less than $5 \mathrm{~m}$ above sea level. While most villages in Prafi valley, such as Tanah Merah, Waseki, Nimbai, Aimasi, Mokwan, Mimbowi and SP-8 are located at about 20 to $25 \mathrm{~m}$ above sea level. A number of 355 pigs comprised of 106 piglets, 74 weaned piglets, 103 growers, 72 sows and 28 boars were observed and measured. Quantitative variables consisted of litter size $(n)$, farrowing size (y) were measured. Research approach was Participatory situation analysis (PSA) applied to approach pig farmers (Conroy, 2005). Interviews using questionnaire were done to gather information from all pig 
farmers. Queries of 20 opened and closed semi-structured questions were asked to the farmers, i.e. characteristics of the farmers, characteristic of farming performances, and characteristic of pig production and reproduction performances. Gender is defined as the role of men and/or women with whom the pig raising is tethered and coded with 1 for man and 2 for woman. The value is quantified where in average of $1-1.5$ men is quoted and where in average of 1.5-2.0 is obtained then women is decided as pig farmers. Educational level is defined as levels of education where a farmer is graduated from certain formal education and obtained a graduated diploma. Education level is defined as 1 for elementary school, 2 for junior high school, 3 for senior high school and 4 for university. Data were analyzed using SPSS version 18.0, an independent-samples $\mathrm{T}$ test (Ott and Longnecker, 2001) was run to compare urban and rural pig farming systems. Levene's test for equality of variance, where variance is not assumed, was evaluated prior to determine significances.

\section{Results and Discussion}

The results of structured questionnaires in how to innovate pig keeping systems effectively for farmers in Manokwari West Papua province Indonesia could be classified into characteristic of pig farmers, characteristic of pig keeping systems, pig production characteristic, getting information of pig keeping systems and perception of opportunities in pig keeping systems.

\section{Characteristic of farmers}

Characteristics of pig farmers in Manokwari, classified into two regions, i.e. urban and rural pig farmers, consist of gender, household members, ages, education levels and experience (Table 1).

Table 1 explained that the mostly gender in pig farmers were men and not different between urban and rural areas. The role of gender was seen in terms of the ownership, in both areas, were dominated by man. Similar finding was also reported by Ropa (2001). Woman was taking only few parts in particular works in pig production cycles such as feeding and cleaning pig houses. Household members belong to respondents were not significantly different. Household members in rural and urban areas are slightly larger than rural areas. This number does not describe what and how many the productive labours are, instead of describing the whole household members. Household members can tell the generation and continuity of household labour available in every household.

Ages of pig farmers relatively shown that the average ages of farmers in urban areas were younger than those rural farmers' ages $(P<0.05)$. However, the ages did not show well depiction of experience and education levels to pig farmers in Manokwari. It can be explained that in mostly of the educational level of farmers is only in basic education. This is why farmers only have experiences in raising pigs from parents. It found that almost all respondents did not take any non-formal or formal education-related pigs in Manokwari.

\section{Characteristic of pig keeping systems}

Characteristics of pig keeping systems in Manokwari grouped into two components, i.e. on-farm and off-farm activities. On-farm characteristic consists of average pigs owned,

Table 1. Characteristics of urban and rural pig farmers in Manokwari

\begin{tabular}{lcc}
\hline \hline \multicolumn{1}{c}{ Characteristic of farmers } & Urban $(\mathrm{n}=20)$ & Rural $(\mathrm{n}=30)$ \\
\hline Gender & & \\
Men & $15(75 \%)$ & $17(57 \%)$ \\
Women & $5(25 \%)$ & $13(43 \%)$ \\
Household member (person) & $6.5 \pm 0.77$ & $5.7 \pm 0.48$ \\
Ages (y) & $41.8 \pm 3.17^{\mathrm{a}}$ & $47.6 \pm 1.70^{\mathrm{b}}$ \\
Education level (\%) & $2.8 \pm 0.36$ & $2.4 \pm 0.37$ \\
No education & $6(30 \%)$ & $17(57 \%)$ \\
Elementary & $4(20 \%)$ & $4(13 \%)$ \\
Junior high & $2(10 \%)$ & $1(3 \%)$ \\
Senior high & $5(25 \%)$ & $2(7 \%)$ \\
Diploma & $2(10 \%)$ & 0 \\
University & $1(5 \%)$ & $6(20 \%)$ \\
Experience (y) & $23.3 \pm 3.40$ & $22.3 \pm 2.90$
\end{tabular}


Table 2. Characteristics of on-farm pig keeping systems in Manokwari

\begin{tabular}{lcc}
\hline \hline \multicolumn{1}{c}{ Characteristic of pig keeping systems } & Urban $(\mathrm{n}=20)$ & Rural $(\mathrm{n}=30)$ \\
\hline Average pigs owned (head) & $8.60 \pm 2.30$ & $7.40 \pm 0.90$ \\
Working hours (hour/day) & $1.80 \pm 0.17$ & $1.60 \pm 0.14$ \\
Pig farming systems & & \\
$\quad$ Free-range & $2(10 \%)$ & $21(70 \%)$ \\
$\quad$ Semi-penned & $7(35 \%)$ & $4(13 \%)$ \\
Penned & $11(55 \%)$ & $5(17 \%)$ \\
$\quad$ Restrained & 0 & 0 \\
Feeding hours (hour/day) & $2.05 \pm 0.31^{\mathrm{a}}$ & $1.64 \pm 0.15^{\mathrm{b}}$ \\
\hline a,b Different superscripts at the same row indicate significantly differences $(\mathrm{P}<0.05)$. &
\end{tabular}

working hours, pig farming systems and feeding hours. While off-farm characteristics comprise of numbers of pig owned, working hours, pig farming systems, feeding hours.

Table 2 shown that average pig owned in both areas is not significantly different. Almost all pigs raised were owned by household members. Although it was found that there are also pigs had already given to pig farmers' families inside and outside Manokwari. Similar finding was also reported in Zimbabwe by Chiduwa et al. (2008). Other on-farm activities such as working hours seemed not significantly different. Working hours per day in each farmer were quite limited. Interaction with housing and pigs can be limited. While visiting housed pigs, the pigs were not tame with farmers that make us not easy to stand closely.

Although penned and semi-penned systems have been done by farmers, there are many farmers who are still keeping their pigs in free-range scavenging systems. Twenty one farmers (70\%) in rural areas are still adopting free-range system due to limited accessibilities to the resources such as housing materials and other social activity constraints. Likewise, in urban areas 11 farmers are rising their pigs in penned system. The similar result of pig farming systems was also recorded by Anil et al. (2006) in India. Feeding hours are spent by farmers in urban areas because they have been keeping their pigs with aims to get income generation $(P<0.05)$. Similar livelihood also informed by Kumaresan et al. (2007). Longer time spent to feed pigs is given as a form of attention and proves to better management of their pig farms. Almost all respondents in rural farmers put their pig pens in around coastal areas and so called docking housed. Only in few farmers who have been applying permanent penned using housing materials such as cement and aluminium sheets as roofs. This practiced also in Western Kenyan pig farmers (Kagira et al., 2010).
Off-farm activities are shown in Table 3, which consists of selling period, type of selling, slaughtering place and decision making in selling pigs. It seems that selling period both in urban and rural areas was similar, i.e. at every semester. It means that pig can be sold while pigs can achieve selling ages, i.e. at six months. Therefore, period of selling is not certainly determined. However, there were some farmers who have entered the agribusiness of pigs always sold pigs in December, where this month is the peak season of demand.

Types of selling pigs in both areas were shown different number. Farmers in urban areas are selling their pigs by bringing it to the local markets, informing the consumers and selling at houses. On the other hand in rural areas, as social market exists, selling pigs are done by informing the consumers and direct payment. Payment can be, as in rural areas, in terms of barters of each other such as married, debts, and tradition affairs. These are occurred in local pig farmers. Slaughtering places where pigs will be slaughtered were found in five means, i.e. at home, retailers, butchers, and selling breeding pigs. Pigs do not have slaughtering houses in Papua in general. Thereby, pigs are always culled in retailers and other local butcher who has an experience in slaughtering pigs. In slaughtering and selling pigs decision was dominantly made by father. As this phenomenon is always occurred in Papuan every-day life pattern, this decision is also happened in decision of selling pigs. Similar arguments were written by Eusebio (1980) and Devendra (2006).

\section{Pig production characteristics}

Table 4 shows that litter size in sows was not significantly different between urban and rural areas. Numbers of litter size are quite equal but relatively lower both in urban and rural areas, i.e. only 3-7 pigs, respectively. Normally a sow can have litter 
Table 3. Characteristics of in-farm pig keeping systems in Manokwari

\begin{tabular}{lrr}
\hline \hline \multicolumn{1}{c}{ Characteristic of pig keeping systems } & Urban $(\mathrm{n}=20)$ & Rural $(\mathrm{n}=30)$ \\
\hline Selling period (times/year) & $4.60 \pm 0.82$ & $4.40 \pm 1.13$ \\
Type of selling & & \\
$1=$ direct selling to the market & $8(40 \%)$ & $4(13 \%)$ \\
$2=$ inform the restaurants, direct payment & $1(5 \%)$ & 0 \\
$3=$ inform the retailers, direct payment & 0 & $1(3 \%)$ \\
$4=$ inform the consumers, direct payment & $7(35 \%)$ & 0 \\
$5=$ inform the consumers, indirect payment & 0 & $2(7 \%)$ \\
$6=$ selling at house & $4(20 \%)$ & $23(77 \%)$ \\
Slaughtering place & $5(25 \%)$ & $4(13 \%)$ \\
$1=$ farm gate & 0 & 0 \\
$2=$ slaughter house & $2(1 \%)$ & $6(20 \%)$ \\
$3=$ retailers & $3(15 \%)$ & 0 \\
$4=$ butcher & $10(50 \%)$ & $20(67 \%)$ \\
$5=$ sell breeding pigs & $13(65 \%)$ & $23(77 \%)$ \\
Decision making in selling & $3(15 \%)$ & $5(17 \%)$ \\
$1=$ husband & $2(10 \%)$ & $2(6 \%)$ \\
$2=$ wife & $2(10 \%)$ & 0 \\
$3=$ both & & \\
$4=$ children & & \\
\hline
\end{tabular}

size more than that 8 up to 12 pigs. This phenomenon occurs due to old ages of sows in entire Manokwari region. Ages of sows in Manokwari are in the culled ages and reached old mature sows. Old mature sows will reduce number of litter sizes and farrowing frequency. Kanis et al. (2008) mentioned litter size as good indicators for selection of better genetic improvement. Due to inbreeding, no introduced breeds are done in Manokwari. This happened due to band regulation which has made by the government to stop imported new breeds. Introducing breeds from outside Papua therefore has to be planned well. Added to this are facilities that will be used and farmers who will be involved in keeping pigs. To protect this region from infectious diseases is the reason of the important policies and regulation as well.

Number of farrowing in sows was also quite lower than as it is. Farrowing times in sow can be two until three times but in fact in Manokwari, many sow in average can be farrowing for only one times. One of qualitative reproduction information is the usage of boars. Many farmers both in urban and rural areas using their own boars ( 9 $\mathrm{hh}=45 \%$ urban and $30 \%$ rural). In rural areas, natural boars, i.e. the free-range local Papua boars were extensively used by natural mating (17 hh=57\%). However, the wild boars were also practised when sows and gilts were roaming around their backyard feeding. By keeping their own boars, farmers will have direct access to use boars soon after gilts and sows entering mating seasons. However, due to boars come from other farmers, exact mating time is not achieved by the sows. Delaying conception of the sows are occurring and experienced by many farmers. It was found that, farming activities without recording was found commonly in Manokwari. Although they have been kept pigs by years, they were forgotten to apply recording in their pig keeping systems. Only few farmers are using recording but not in details. Actually they have considered it but it seems that they could not know which data has to be recorded and how

Table 4. Characteristics of pig production and reproduction cycle in Manokwari

\begin{tabular}{lrr}
\hline \hline \multicolumn{1}{c}{ Characteristic of pig keeping systems } & Urban $(\mathrm{n}=20)$ & Rural $(\mathrm{n}=30)$ \\
\hline Litter size (piglets/farrow/sow) & $5.50 \pm 2.13$ & $5.80 \pm 2.33$ \\
Numbers of farrowing (times/year) & $1.50 \pm 0.51$ & $1.50 \pm 0.73$ \\
Using boars & & \\
1= own & $9(45 \%)$ & $9(30 \%)$ \\
$2=$ rent & $7(35 \%)$ & 0 \\
3= natural & $4(20 \%)$ & $17(57 \%)$ \\
4= wildpig & 0 & $4(13 \%)$ \\
Recording (yes/no) & & \\
No=1 & $17(85 \%)$ & $26(87 \%)$ \\
Yes=2 & $3(15 \%)$ & $4(13 \%)$ \\
\hline
\end{tabular}


to begin. Recording in terms of productivities and economics can benefit for farmers. Without recording farmers will not know whether farmers are efficient in using inputs and producing sufficient outputs. Using recording, all resources farmers will be allocated effectively. Therefore, in pursuing farmers having knowledge of recording, a technical aid should be offered and guided by extensionsits or experts.

\section{Conclusion}

It can be concluded and recommended that pig keeping should be improved to sustain pig farming systems in Manokwari Papua. Education may be improved by provide informal and skilful education. Pig owner should be increased. Working hours must be increased. Promoting keeping pig in the pens should be done by farmers. Litter sizes both in urban and rural are low, therefore this needs further improvement. Recording pig productivities must be done by every farmer.

\section{References}

Anil, K. S., P.C. Saseendran, Joseph Mathew and M. Murugan. 2006. Effect of management systems on growth performance of two genetic groups of pigs. Tamilnadu J. Vet. Anim. Sci. 2: 229-233.

Basna, A. 2011. Statistik vital ternak babi yang dipelihara dibawah kelapa sawit dan yang dikandangkan. Skripsi Fakultas Peternakan, Perikanan dan IImu Kelautan, Universitas Negeri Papua, Manokwari.

Berkmann, R. 2006. A project in Papua New Guinea and Indonesian province of Papua is seeking to enhance a traditional village-based food production systems. Report. ACIAR.http://www.aciar.gov.au/system /files/node/649/Partners+Winter+Editio $\mathrm{n}+2006+$ Sweet+Potato+\%2526+pig+s ystem.pdf. Accessed 17 March 2008.

Chiduwa, G., M. Chimonyo and T. E. Halimani. 2008. Herd dynamic and contribution of indigenous pigs to the livelihood of rural farmers in a semi arid area of Zimbabwe. Trop. Anim. Health Prod. 40: 125-136.
Conroy, C. 2005. Participatory livestock research: a Guide. ITDG Publishing, Warwickshire, UK.

Deka, R., W. Thorpe, M. L. Lapar and A. Kumar. 2007. Assam's pig sub sector: current status, constraints and opportunities. ILRI, New Delhi, India.

Devendra, C. 2006. Perspectives on animal production systems in Asia: Review article. J. Livest. Sci. 105: 229-242.

Eusebio, J. A. 1980. Pig production in the Tropics. Intermediate tropical agriculture series. W. J. A. Payne (ed). Longman group Ltd, Essex, UK.

Iyai, D. A. 2008. Inovation of pig keeping system in pig farmers at Manokwari, West Papua Province, Indonesia. Tesis Wegeningen University, The Netherlands.

Kagira, J. M., Paul W. N. Kanyari, I. Maingi, S. M. Githigia, J. C. Ng'ang'a and J. W. Karuga. 2010. Characteristic of the smallholder free range pig production systems in Western Kenya. Trop. Anim. Health Prod. 42: 865-873.

Kanis, E., K. H. De Greef, A. Hiemstra and J. A. M. van Arendonk. 2008. Breeding for societally important traits in pigs. J. Anim. Sci. 83: 948-957

Kumaresan, A., K. M. Bujarbaruah, K. A. Pathak, B. Chetri, S. K. Das, A. Das and S. K. Ahmed. 2007. Performance of pigs reared under traditional tribal low input production system and chemical composition of non-conventional tropical plants used as pig feed. Livest. Sci. 107: 294-298.

Lekule, F. P. and N. C. Kyvsgaard. 2003. Improving pig husbandry in tropical resource-poor communities and its potential to reduce risk of porcine cysticercosis. Review article. Acta Tropica 87: 111-117.

Lemke, U., B. Kaufmann, L. T. Thuy, K. Emrich, and A. V. Zarate. 2006. Evaluation of smallholder pig production systems in North Vietnam: Pig production management and pig performances. Livest. Sci. 105: 229243.

Muys, D. and G. Westenbrink. 1998. Pig keeping in the tropics. Agrodok-Series No.1. Agromisa, Wageningen, The Netherlands. 
Ott, R. L. and M. Longnecker. 2001. An introduction to statistical methods and data analysis. $5^{\text {th }}$ edn. Texas $A \& M$ University, Wadsworht Group USA.

Peters, J. 2001. Local human-sweet potatopig systems: Characterization and research in Irian Jaya, Indonesia with limited reference to Papua New Guinea. A $2^{\text {nd }}$ literature review: Poverty Alleviation and Food Security Through Improving the Sweet Potatoes-Pig Systems in Indonesia and Vietnam. International Potato Center (CIP).
Ropa, M. 2001. Sistem pemberian pakan pada usaha peternakan babi rakyat di Kecamatan Manokwari. Tesis, Universitas Cenderawasih, Papua. 